\title{
Influence of Precast Member Corbels on Seismic Performance of Precast Beam-Slab-Column Joints
}

\author{
Hongtao Liu $\mathbb{D},,^{1,2}$ Pengchao Kong, ${ }^{1}$ and Taoping Ye \\ ${ }^{1}$ School of Civil and Transportation Engineering, Beijing University of Civil Engineering and Architecture, Beijing 100044, China \\ ${ }^{2}$ Key Laboratory of Urban Security and Disaster Engineering of the Ministry of Education, Beijing University of Technology, \\ Beijing, 100124, China \\ ${ }^{3}$ The First Construction Engineering Company Ltd. of China Construction Second Engineering Bureau, Beijing 100176, China \\ Correspondence should be addressed to Hongtao Liu; liuhongtao@bucea.edu.cn
}

Received 21 June 2021; Revised 22 September 2021; Accepted 5 November 2021; Published 6 December 2021

Academic Editor: Dario De Domenico

Copyright (c) 2021 Hongtao Liu et al. This is an open access article distributed under the Creative Commons Attribution License, which permits unrestricted use, distribution, and reproduction in any medium, provided the original work is properly cited.

\begin{abstract}
To improve the construction efficiency of precast structures, reinforced concrete corbels acted as support members are the most common connection method. This work presents the performance of a specific beam-to-column connection using corbels with different anchorage arrangements in precast beam-slab-column interior joint taken out from precast underground subway station. This paper investigates the performance of a specific full-scale precast concrete beam-slab-column interior joint with corbels and various connected methods subjected to low-cycle repeated loading. Meanwhile, the influences of concrete corbels (including column- and beam-end corbels) on the shear strength and deformation are investigated. The analyses results indicated that (1) corbels of the laminated beam (composite beam) can obviously improve the shear stress of the core region, which was beneficial for specimen design followed the strong-joint-weak-member concept; (2) a simplified approach to deal with the uneven thickness of corbels in the core region was proposed, which was utilized to study the effect of thickness on the shear performance of the core region; (3) the shear stress increased with respect to the compression stress, and the shear strain had a trend of decreasing according to calculating results using modified compression field theory; and (4) the deterministic expressions were proposed to predict the designed load of column corbels based on three different connection methods between laminated beams and core region of joint.
\end{abstract}

\section{Introduction}

The precast concrete structures offer many advantages over conventional construction, the most important of which is the short onsite construction time, lower traffic impact, high-quality control, and environmental protection [1]. So, they have been extensively investigated and employed in a wide variety of the above structures. Exactly for these, the precast structures also have many shortcomings, such as poorer integrality, insufficient energy consumption capacity, more difficult on-site installation, and connection methods of joints. Another issue to be commended was that the available full-scale tests on the seismic behavior of connections, especially for underground structures, can be characterized as poor. The seismic performance of the precast structure relies largely on the mechanical behavior of joints, which was also reached and confirmed by other studies [2]. In order to circumvent the drawbacks of the precast structure and directly adopt the existing cast-inplace concrete specification, the assembled monolithic concrete structures combined postpouring concrete and precast element are studied and have been recommended for applications in underground stations $[2,3]$. At present, precast underground structures are characterized by relatively complex conditions in terms of large-scale, complication, and diversified, which are different from that of aboveground structures. Moreover, the seismic performance of the underground structure is not as safe as one thought, which has been validated against the damages of some tunnels and stations $[4,5]$. Therefore, the seismic behavior of 
underground structures should be first validated against the experimental results before they were applied. Unfortunately, the seismic performance of precast structures was examined in a limited number of studies. Until now, fullscale seismic experiments were the main methods to study the mechanical properties of precast joints, the reason of which was that the lack of in-depth understanding of contact performance between precast elements made it difficult to express the real mechanical properties, which could be exhibited during a deformation stage [6-8].

There are also many studies on the seismic performance of beam-column joints of aboveground structures. Megally et al. [9] studied the seismic performance of segment-tosegment joints in the precast segmental concrete bridge and indicated that external tendons improved ductility and displacement capacity. Seible and Latham [10] attempted to study the effectiveness of interface dowels for horizontal shear transfer in connection with clean and specially roughened contact surfaces. Brooke et al. [11] conducted tests on four beam-column joints with large diameter and high-strength reinforcement, which solved the high level of reinforcement congestion. Kashyap et al. [12] performed experiments on 14 FRP-to-masonry bond tests and presented a new FRP-to-masonry bond model. Priestley [13-15] studied the seismic performance of precast concrete frame buildings, beam-column joints, and shear walls and put forward several design suggestions. Shafaei et al. [16, 17] studied the seismic performance of beam-column joints having either nonseismic or seismic reinforcement details, and the results indicated that rehabilitated methods can recover the mechanical properties. Elsanadedy [18] attempted to develop new precast moment connections for increasing the progressive collapse robustness of precast buildings. Huang et al. [19] presented a novel type of precast concrete beam-column connection including a hinge shaft and multislit devices, and the seismic performance of the proposed connections was superior to that of the monolithic joint. Li et al. [20] presented a method for improving the seismic performance of RC joints using ferro-cement jackets with embedded diagonal reinforcements. The above-mentioned research results have promoted the development and application of precast structures.

The assembled monolithic concrete subway station contained the amount of joints located in the transverse direction and longitudinal direction. The joints of columnbasement [21], sidewall-basement [22], and column-laminated slab (composite slab) [23] have been studied and detailed in a standalone paper. Tests of full-scale precast and cast-in-place specimens showed that precast concrete specimens were capable of matching the overall performance of the monolithic connection. Exactly for these, compared to joints in the transverse direction, the performance of the beam-slab-column joint located in the longitudinal direction should be considered due to the complex assembled process and the force transmission mechanism. In order to improve the convenience of construction, various anchorage arrangements including grouted splices, straight lapping splices, and bend-up cross lapping splices were utilized to connect discontinuous reinforcement bars reserved on the outside of precast concrete elements. It was worth mentioning that precast elements with corbels can improve the assembled efficiency and reduce on-site support components. However, the available literature on the behavior of concrete corbels can be characterized as poor. In particular, the effect of the connection types between precast laminated beams and core region on the load subjected to corbel was insufficient. Additionally, the corbel also increases the shear area of the core region.

Apart from the influence of the corbel on the core region of the joint, the corbel is an easily damaged part due to the poor detailing of bearing pad position, and the loading capacity cannot be fully recovered by appropriate retrofitting solutions. Therefore, investigators have studied rehabilitation to improve the mechanical properties of the corbel. Gulsan and Shaikhan [24] attempted to produce a steel confining system for the rehabilitation of damaged concrete corbels. Experimental results showed that the proposed rehabilitation technique can improve load capacity and ductility. Souza et al. [25] presented the procedures adopted for repairing and strengthening the damaged concrete corbel belonging to an industrial biomass boiler, and the strut-andtie model was utilized to verify the force mechanism of corbels. Tsang [26] explored an innovative idea of upscaling decorative architectural elements to fulfill more stringent performance and enhance the mechanical properties of the building structure. Ahmad et al. [27] conducted tests on nine members attached carbon fibre reinforced polymers (CFRP), and the result showed that load capacity of corbels was significantly improved and U-wrapping was the recommended arrangement for strengthening corbels. Simultaneously, many studies [28-31] have indicated the mechanical behavior of the concrete corbels can be improved by wrapping the carbon fibre reinforced polymers. Based on reviews from previous research, the damage of concrete corbels was largely affected by the bearing pad position. However, the connection mode of the components that acted on the concrete corbel can also indirectly affect the damage of corbels. For the precast beam-slab-column joint, the connected types of precast elements that acted on the concrete corbels were various (fixed connection, hinged connection, and free connection). So, substantial attention should be paid to concrete corbels.

In light of the above-mentioned background, this paper aims at investigating the seismic performance of full-scale precast beam-slab-column interior joints with corbels and several connection modes of discontinuous reinforcement, as shown in Figure 1. Meanwhile, another full-scale cast-inplace specimen is built monolithically to serve as the control. The present work is organized as followed. Firstly, details of the experimental program of precast and cast-in-place specimens are present. Then, the behavior including failure mode, load-carrying capacity, and strain distribution of specimens subjected to low-cycle repeated loading is investigated. Based on the experimental results and the modified compression field theory (MCFT) [32, 33], the influence of the shear behavior of the core region of the beam-slab-column interior joint is studied with respect to two parameters: the compression stress and in-plane 


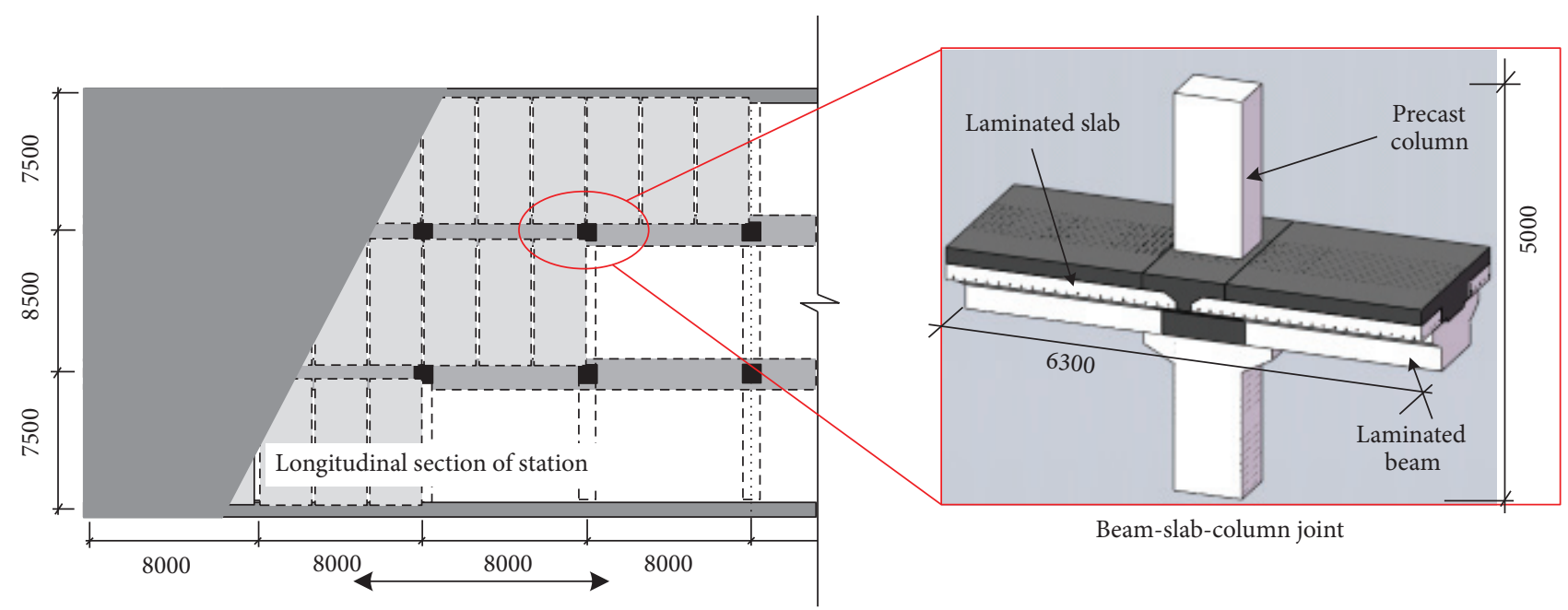

Figure 1: Structure diagram of the subway station and isolated reinforced concrete beam-slab-column joint.

thickness of joint, which lays the foundation for the numerical model of precast joints. Finally, an exploratory study of the influence of different connection modes of laminated beam and core region on the designed load subjected to corbels is presented. The research outcome of this study will provide an in-depth understanding of the application of precast elements in underground structures.

\section{Experimental Program}

To further address the above-mentioned deformation and damage mechanisms of real joints, two full-scale beam-slabcolumn joint specimens with slabs were designed and prepared. One specimen was assembled with different precast elements and noted as precast middle beam-slabcolumn joint (PMJ). The second specimen was built monolithically to serve as the control and named as cast-inplace middle beam-slab-column joint (CMJ). The specimens were taken out from a two-story three-span subway station, with $7.6 \mathrm{~m}$ of story height and $22.9 \mathrm{~m}$ of span length, as shown in Figure 1.

2.1. Design and Description of Specimens. Combining with the loading equipment of $40,000 \mathrm{kN}$ capacity multifunctional electrohydraulic servo loading system and the overall bending moment diagram of the cast-in-place monolithic subway station, the construction dimensions of specimens with approximately $5,000 \mathrm{~mm}$ in height and $6,300 \mathrm{~mm}$ in length were adopted. The precast specimen was composed of two precast column elements, two semi-precast beam elements, and four semi-precast slab elements. The assembled process was detailed in a standalone paper [34]. It was noted that the slab width was designed to take into account the limits due to the available installed space of the loading system. So the width of the slab was $2,400 \mathrm{~mm}$, which was assumed equal to 6 times the thickness [35].

Various connection types, such as grouted sleeves, lapping connection, and cast-in-place connection, were adopted for the specimen PMJ. Twenty-four grouted sleeves were utilized to connect the precast top column and low column, which have a rectangular cross-section with $700 \mathrm{~mm} \times 900 \mathrm{~mm}$; the precast upper and lower columns were connected by the core region. The details of longitudinal and transverse reinforcement were given in references $[2,36]$. In order to improve the construction convenience, the overlapping connection of steels was adopted for the semi-precast beam and concentrated in the beam-column joint core region. It was worth mentioning that the overlapping connection was of crucial importance for the mechanical performance of specimens, so the anchorage length was $900 \mathrm{~mm}$, which ensured enough connecting strength of precast beams [37], as shown in Figure 2. For four precast slabs, the cross-lapping connection was adopted according to the bend-up reinforcement at the ends of semi-precast slabs to avoid contradictory positions of steel bars between the beam and slab. The precast slabs and cast-in-place concrete slabs were connected by rough concrete interfaces and erecting steel bars. Since the dead and live loads of the slab surface were not considered, the function of slabs only provided the strengthening effect on the laminated beam. More details about slab connection were available in reference [2]. In addition to precast specimens, the geometry and dimensions of the cast-in-place specimen were the same except for obvious differences including continuous steel and construction method and excluding corbels.

Exactly for the steel connection, the corbel connection acted as an important addition of devices to provide the installed convenience. So corbel strength of beam and column played an important role in transferring pressure from each precast element. The outer edge height of the beam-corbel, h1, was $150 \mathrm{~mm}$, which was a controversy regarding the recommended size as the code for the design of concrete structures [37]. For the corbel of the precast column, the cross-sectional dimension and shape were illustrated in Figure 3, and the same contradiction still exists. The reinforcement steels in the corbel of column and beam met the structural requirement, for example, diameter, spacing, reinforcement ratio, and the control index of cracking. Additionally, the ratio of reinforcement was illustrated in 


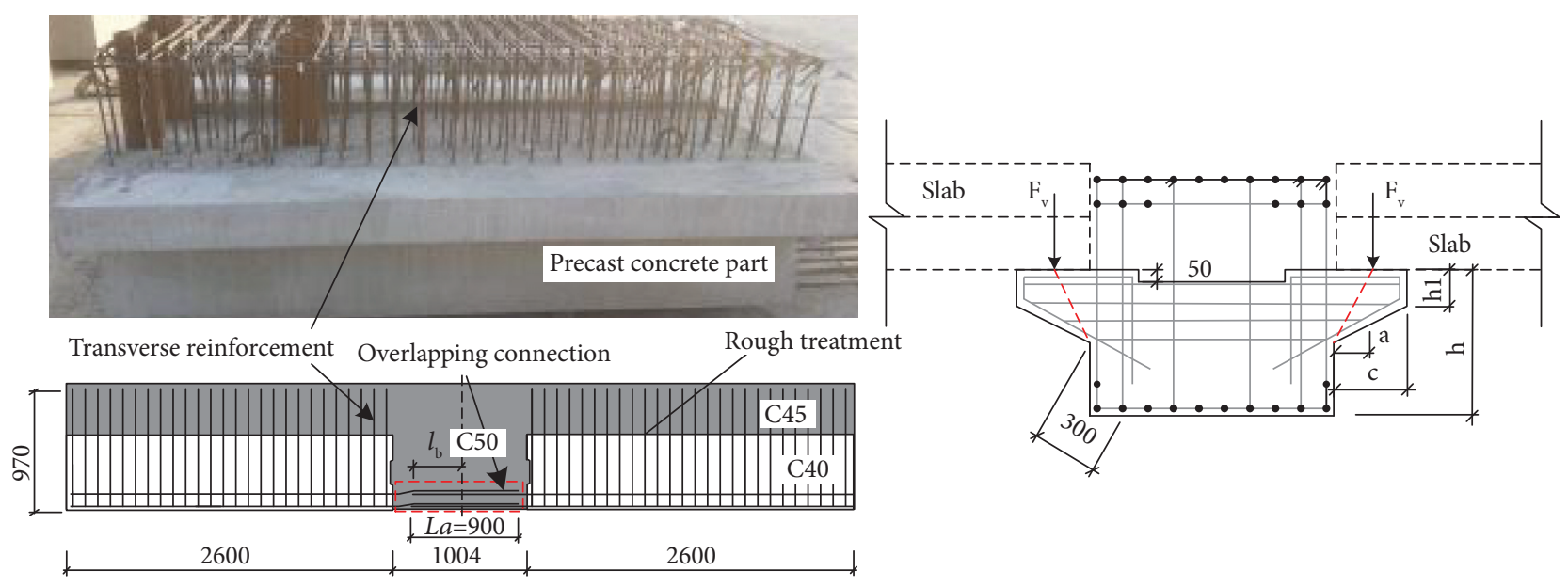

(a)
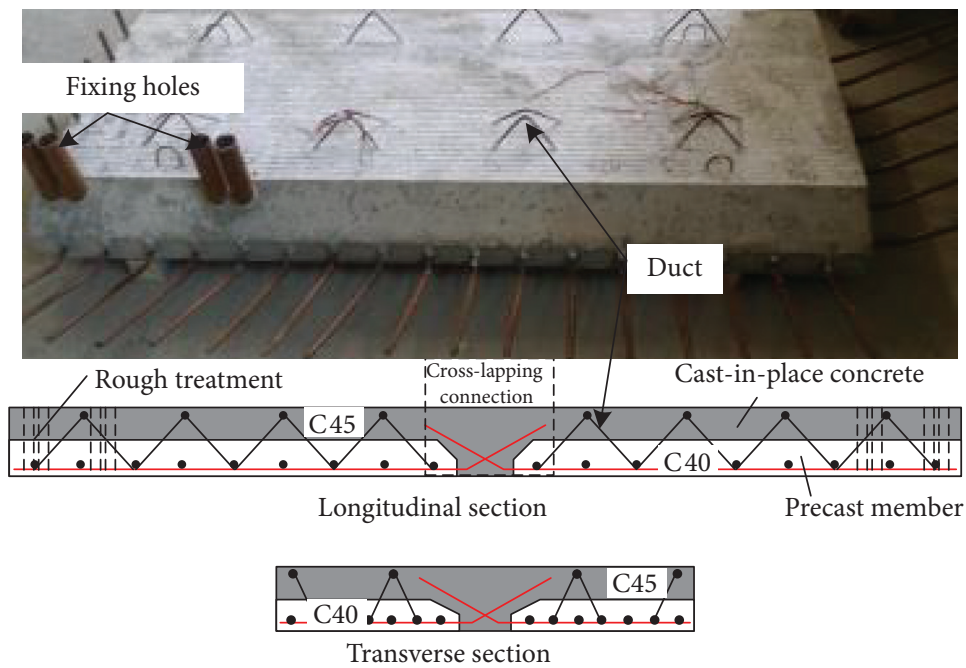

(b)

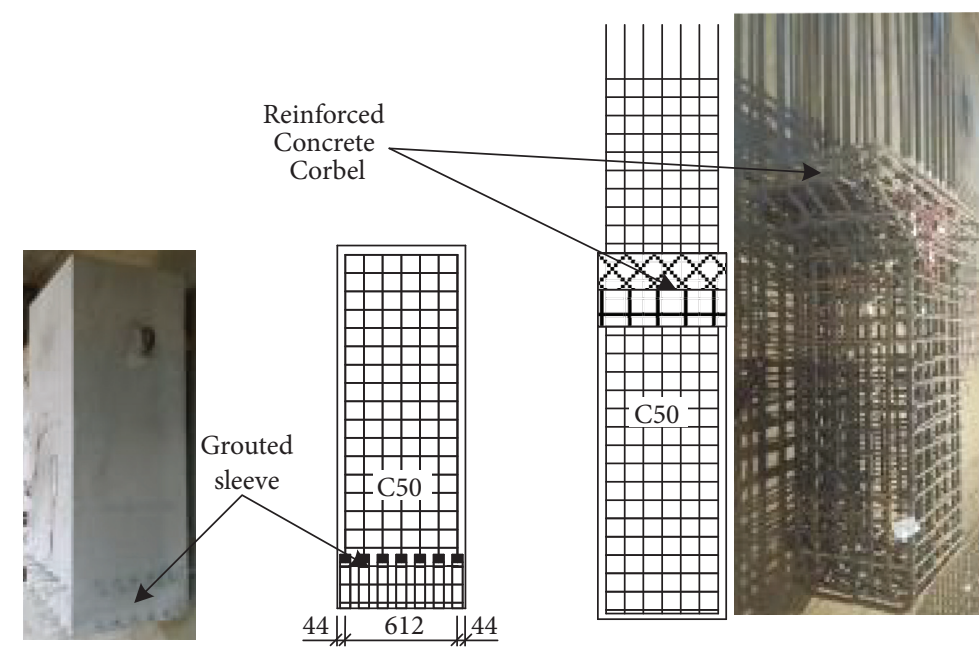

Precast upper column

Precast lower column

(c)

Figure 2: Connection structure of each member (unit: $\mathrm{mm}$ ): (a) precast beam connection, (b) precast slab connection, and (c) precast column connection. 


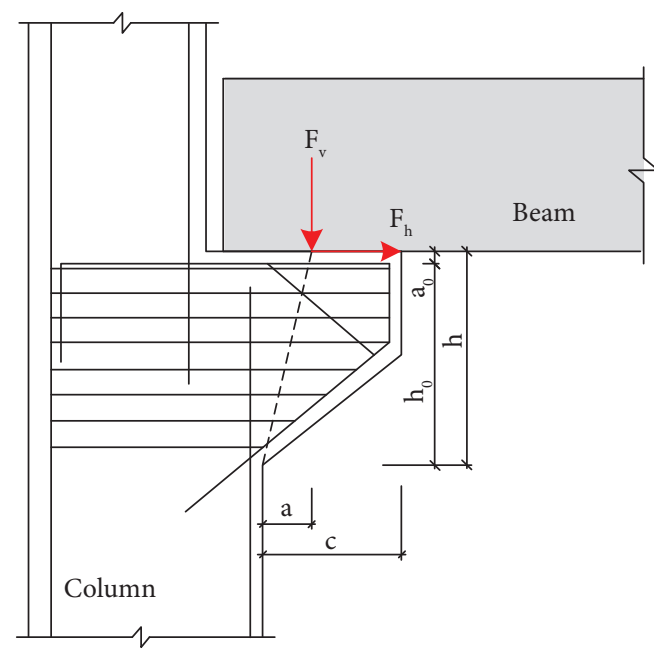

(a)

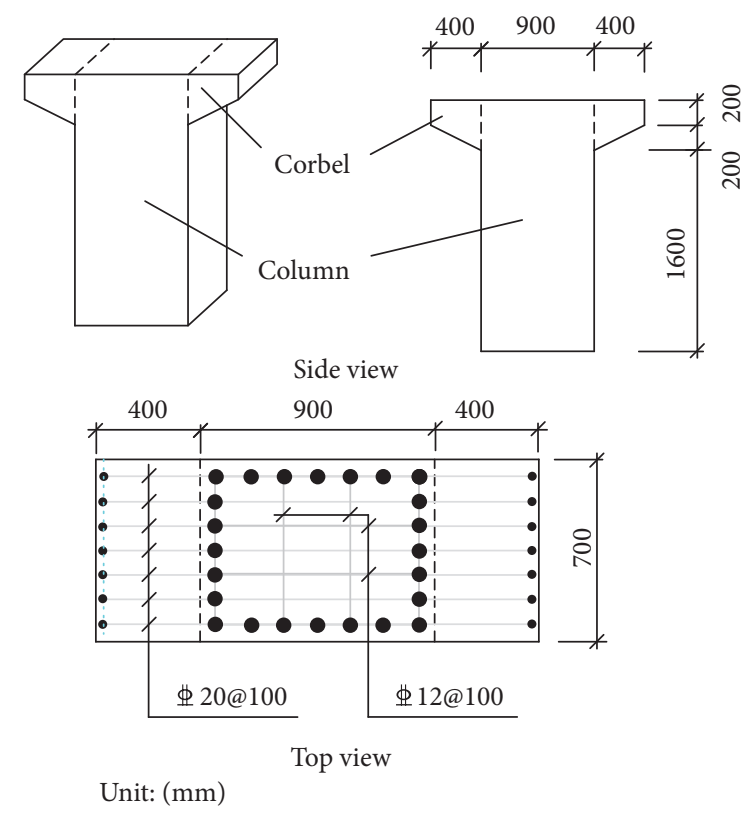

(b)

FIGURE 3: Schematic diagram of corbel column: (a) schematic diagram of corbel and (b) corbel shape of precast lower column.

equations (1) and (2). $f_{t k}$ was the stranded for the tensile strength of concrete prism, which was $1 / 10$ of the compressive strength; $f_{y}$ was the yielding strength of steel; $b$ was the width of corbel; $h_{0}$ was effective height; $A_{s}$ was the steel area of corbel; and $F_{v}$ and $F_{h}$ was the vertical and horizontal force subjected to the corbel, respectively. According to ACI318-14 [38] and studied results [39], the mechanical ratio of main and secondary steel bars was provided, and the expressions of shear strength of corbel were given as equation (3). But how to calculate the design load $V_{u}$ and the influencing factors were not clear.

$$
\begin{aligned}
A s & \geq \frac{F_{v} a}{0.85 f_{y} h_{0}}+1.2 \frac{F_{h}}{f_{y}} . \\
F v & \leq \beta\left(1-0.5 \frac{F_{h}}{F_{v}}\right) \frac{f_{t k} b h_{0}}{0.5+\left(a / h_{0}\right)} . \\
v & \leq \frac{V_{u}}{b d f_{c}} .
\end{aligned}
$$

2.2. Material Properties. The specimens were mainly composed of different grade concrete, different types of steel bars, grouted sleeves, and cementitious grout for the splice. The concrete grade of the precast column and other semiprecast elements including slabs and beams were C50 and C40, respectively. In order to improve the bonding strength between precast elements and postpouring concrete (laminated beams and slabs), the grade of postpouring concrete should be improved to $\mathrm{C} 45$, and the contact surfaces were roughened. It was worth mentioning that the concrete grade of the core region (overlap region of beam, column, and slab) was designed in accordance with column strength, as well as its grade of concrete was C50. The concrete grade of each element is shown in Figure 2. The measured mechanical properties of steel and concrete were obtained by material tests and summarized in Table 1 [2]. Additionally, the properties of grouted sleeves and cementitious grout for splice were shown in previous studies $[22,40]$.

2.3. Test Content and Instrumentation Distribution. Different connection methods including grouted sleeves, corbels, and development connections were distributed around the core region of the beam-slab-column joints. The grouted sleeves improved stiffness and strength of the connection region (precast column connected with grouted sleeves); corbels connection increased sliding distance (precast beams and columns were connected by corbels. Meanwhile, precast slabs and beams were connected by corbels); and assembled seams reduced the connection quality of each precast part; and the development connection of steels increased the complexity of the connection region. To contribute towards a better understanding of these differences of deformation and strength between precast and cast-in-place specimens, the response quantities of measuring content included deformation, strength, and strain. Details of measuring instrumentation were illustrated in Figure 4. Each test specimen was subjected to quasi-static load reversals that simulated earthquake loads. Reverse cyclic loading was applied at the two ends of the beam in opposite directions, as shown in Figure 5. The cyclic loading was generally load-controlled up to yield load at first and displacement-controlled up to failure with increasing displacement ductility coefficient [41]. Test setup and loading law were detailed in a standalone paper [34]. In addition, the load applied on the beam-end was removed when the 
TABLE 1: Mechanical properties of materials.

\begin{tabular}{|c|c|c|c|c|c|}
\hline Materials & Grade & $d(\mathrm{~mm})$ & $f_{y}(\mathrm{MPa})$ & $f_{u}(\mathrm{MPa})$ & $E_{s}(\mathrm{MPa})$ \\
\hline \multirow{5}{*}{ Reinforcement } & \multirow{4}{*}{ HRB 400} & 28 & 420.6 & 593.9 & $2.1 \times 10^{5}$ \\
\hline & & 25 & 454.4 & 617.0 & $2.1 \times 10^{5}$ \\
\hline & & 22 & 446.5 & 574.9 & $2.1 \times 10^{5}$ \\
\hline & & 18 & 436.2 & 564.1 & $2.0 \times 10^{5}$ \\
\hline & НРВ300 & 10 & 309.3 & 451.3 & $2.20 \times 10^{5}$ \\
\hline \multirow{4}{*}{ Concrete } & Strength & $f_{c u}(\mathrm{MPa})$ & $f_{c}(\mathrm{MPa})$ & $E_{c}(\mathrm{MPa})$ & $v$ \\
\hline & C40 & 45.4 & 26.6 & $3.14 \times 10^{4}$ & 0.2 \\
\hline & $\mathrm{C} 45$ & 51.1 & 29.3 & $3.38 \times 10^{4}$ & 0.2 \\
\hline & $\mathrm{C} 50$ & 55.9 & 32.7 & $3.33 \times 10^{4}$ & 0.2 \\
\hline
\end{tabular}

Note: $d$ is the diameter of steel; $f_{u}$ is the ultimate strength of steel; $E_{s}$ and $E_{c}$ are steel and concrete elastic modulus, respectively; $f_{c u}$ is the compressive strength of concrete cube; $f_{c}$ is the compressive strength of concrete prism; and $v$ is Poisson's ratio.
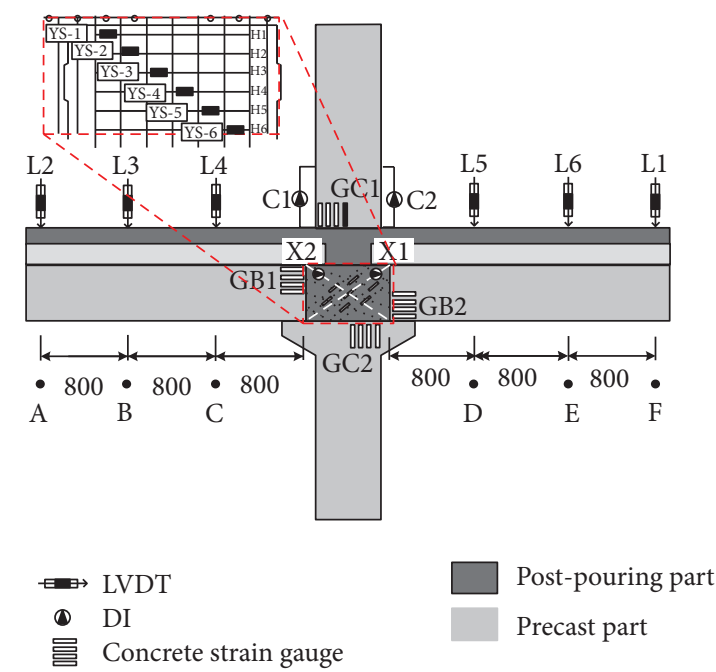

FIGURE 4: Measuring points arrangement for specimens.

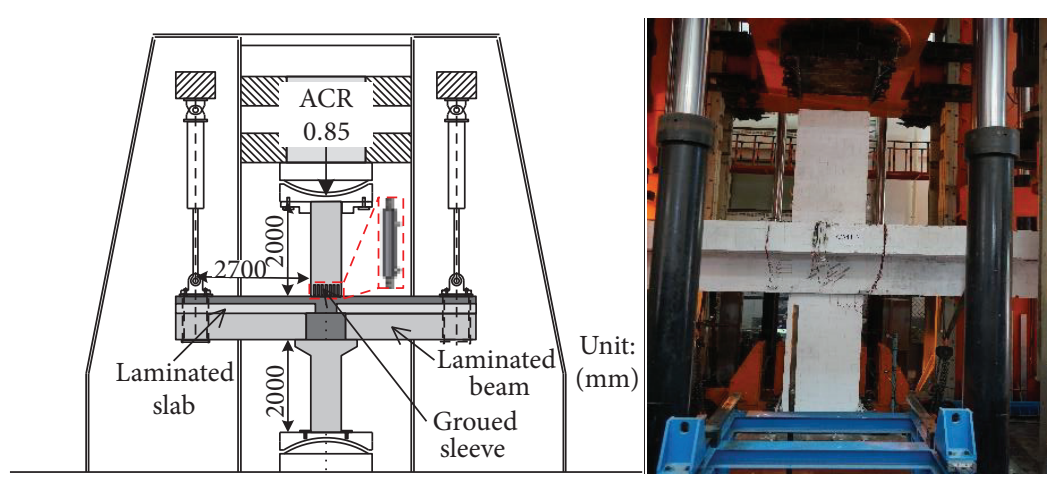

Figure 5: Test setup.

strength decreased to $85 \%$ of the maximum achieved strength and the dial indicator automatically obtains test data at a frequency of $50 \mathrm{~Hz}$.

\section{Experimental Results and Discussion}

3.1. Overview of Failure Pattern. The failure process of specimens was divided into four main damage stages (cracking stage, yielding stage, limiting stage, and failure stage) distinguished by forcing state. The final failure mode of both specimens including failure location and cracking distribution was different obviously because of the different construction methods of the precast specimen and cast-inplace specimen. The main damage of cast-in-place specimen was distributed in the beam, slab, and core region of joints. Mostly, it exhibited well-distributed fine flexural cracking in the beam and slab, and shear cracks were found in the core region. However, the cracks of the precast specimen were concentrated in the gap provided between the precast element and postpouring concrete, that is, the interface of 
laminated slabs, contacting faces of the precast beam, and postpouring core concrete. It was noteworthy that there was no indication of brittle damage in the specimens. The specific failure process of each specimen was as follows.

In terms of the failure mode, two reference specimens failed in different ways [23, 36], as shown in Figure 6. Compared with the cast-in-place specimen, the following observation was realized. Although the crack propagation process of the precast specimen during the cyclic tests was identical to the respective process observed in the cast-inplace specimen, the failure modes of both were different, which were mainly reflected in the following two aspects. Firstly, the construction connected method of cast-in-place and precast specimens was different. Corbels of semi-precast columns lead to redistribution of internal force in the beam. Meanwhile, beam corbels were equivalent to increasing the shear region of the core region. Secondly, the bonding strength of the interface between semi-precast elements and postpouring concrete including core region and postpouring slab was weak. It was noteworthy that the slight damage of the concrete laminated slab was observed due to the strengthening effect of the slab on the beam, as reported by Wang et al. [35].

3.2. Hysteretic Response and Envelopes. The obvious four forcing stages including elastic, yielding, stable, and descending stages were observed in the loading process from the specimen CMJ. Unfortunately, partial data of specimen $\mathrm{PMJ}$ in the positive direction become invalid due to the equipment strength self-protection, which was never considered before testing design. However, partial results, including yielding state, peaking state, and ultimate state, can be reached from backbone curves. The equivalent bending moment method [2] was used to determine the yielding state for each specimen, and the peaking state was taken as the maximum strength value, and the ultimate state was defined, arbitrarily, as a $25 \%$ drop in strength from the peak value. It can be seen from Table 2 that the yielding strength of the specimen PMJ was about 1.2 times that obtained from specimen CMJ, but the yielding displacement was 0.7 times that of specimen CMJ. This can at least illustrate that the precast specimen has excellent integrity performance in the early loading stage. The precast concrete joint was capable of matching the ultimate strength of the cast-in-place specimen in the positive direction, while there was an obvious difference in the negative bending moment direction. The reason for the above observation was that the two joints differed in the arrangement of the connections, especially corbels of beams. Combining with the failure mode of testing specimens, it can be seen that the failure of the castin-place specimen was mainly concentrated in the core region, and the damage of the precast specimen was focused on the bottom of the core region. Given that the core region of joints was divided into upper and lower parts, the corbel of beams improved the shear strength of the upper part of the core region, which will be discussed in the later section.

Exactly for strength and displacement, ductility was an important index for evaluating the seismic performance of reinforcement concrete specimens. The cast-in-place specimen attained a displacement ductility level of about 5.02, while the ductility of the precast specimen was 8.27 , which was 1.65 times more than that of the former specimen, as shown in Table 2. The main reason for larger ductility was that the opening gap of the semi-precast beam and the corbel of the column contribute to the global deformation in the later loading. A similar explanation of the above finding had also reported by Liu et al. [23].

3.3. Strain of Grouted Sleeves. The connection performance of grouted sleeves directly affected the normal use state of the structures even triggered the collapse. The spliced-bar strain ratio was obtained by dividing the spliced sleeve strain with the splice-end bar strain, which was utilized to evaluate the deformability of structures [21,42]. The axial strain of grouted sleeves encased in a column with concrete was measured with strain gauges, which were located at the bottom of the precast column, as shown in Figure 4. Meanwhile, the axial strain was compared in Figure 7 to the corresponding steel strain in the cast-in-place specimen. It can be seen that the strain values of grouted sleeves were much smaller than those of steels, and they were approximately 6 times less than those of grouted sleeves when the drift was $3 \%$ in the positive moment. Unfortunately, the axial strain of grouted sleeves in the negative load-carrying capacity was of no avail, but the strain of grouted sleeves was smaller than that of steels from the initial forcing stage. On the whole, the deformation of the grouted sleeve section was much smaller than that of the corresponding section in the cast-in-place specimen. This phenomenon was also found in previous research results [21]. Therefore, the reducing effects of grouted sleeves on the crosssection deformation should be carefully considered in the design of precast structures in seismic areas.

3.4. Concrete Strain. Based on the aforementioned test results, there was no obvious damage in the grouted sleeves region. The bonding strength of the surrounding concrete was weak because of the smooth surface of grouted sleeves. Therefore, the concrete strain corresponding to grouted sleeves (reinforcement steel) was measured in Figure 8. One can see from relationship curves that grouted sleeves (steels) can deform compatibly with surrounding concrete and avoid bond slipping cracks. In general, the concrete strain was greater than that of corresponding grouted sleeves or steels. For example, the maximum strain was $400 \mu \varepsilon$, as shown in Figure 8(a). Mostly, the strain value of specimen CMJ was about 6 times more than that of specimen PMJ, as shown in Figure 8(b), which demonstrated that concrete at the column base was almost closed to failure.

\section{Forcing Analysis of Core Region}

The designed concept of strong-joint-weak-member and strong-column-weak-beam was recommended for the reinforced concrete structures in seismic regions [43, 44], which significantly improved the seismic performance of structures, especially aboveground structures. Meanwhile, 


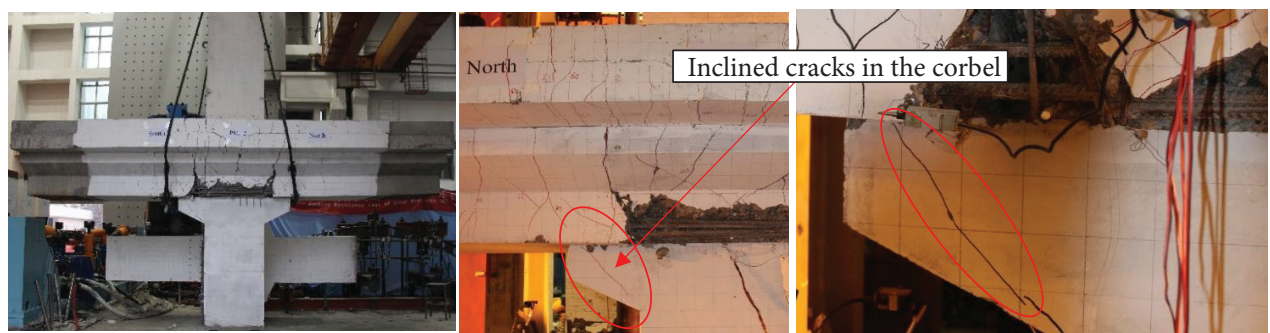

FIGURE 6: Distribution of cracks of precast joint (PMJ).

TABLE 2: Feature point values of test results.

\begin{tabular}{|c|c|c|c|c|c|c|c|c|c|}
\hline Specimens & Position & Loading direction & $\Delta_{y}(\mathrm{~mm})$ & $P_{y}(\mathrm{kN})$ & $\Delta_{p}(\mathrm{~mm})$ & $P_{p}(\mathrm{kN})$ & $\Delta_{u}(\mathrm{~mm})$ & $P_{u}(\mathrm{kN})$ & $\mu$ \\
\hline \multirow{4}{*}{ CMJ } & \multirow{2}{*}{ North } & Negative & 13.81 & -891.91 & 89.65 & $-1,193.00$ & 130.29 & $-1,014.05$ & \multirow{2}{*}{6.62} \\
\hline & & Positive & -19.90 & $1,588.81$ & -42.15 & $1,839.00$ & -75.68 & $1,563.15$ & \\
\hline & \multirow{2}{*}{ South } & Negative & 25.67 & $-1,099.07$ & 50.30 & $-1,437.00$ & 83.90 & $-1,221.45$ & \multirow{2}{*}{3.42} \\
\hline & & Positive & -29.70 & $1,340.04$ & -48.65 & $1,596.51$ & -105.92 & $1,357.03$ & \\
\hline \multirow{4}{*}{ PMJ } & \multirow{2}{*}{ North } & Negative & 11.56 & $-1,036.17$ & 32.70 & $-1,189.00$ & 112.00 & $-1,010.65$ & \multirow{2}{*}{9.69} \\
\hline & & Positive & -14.52 & $1,802.53$ & - & - & - & - & \\
\hline & \multirow{2}{*}{ South } & Negative & 15.59 & $-1,226.14$ & 22.70 & $-1,334.00$ & 106.70 & $-1,133.90$ & \multirow{2}{*}{6.84} \\
\hline & & Positive & -18.85 & $1,800.24$ & - & - & - & - & \\
\hline
\end{tabular}

Note. $\Delta_{y}, \Delta_{p}$, and $\Delta_{u}$ present the yielding displacement, peaking displacement, and ultimate displacement, respectively; $P_{y}, P_{p}$, and $P_{u}$ stand for the yielding strength, peaking strength, and ultimate strength, respectively; $\mu$ was displacement ductility that was obtained as the ratio of ultimate displacement $\Delta_{u}$ to yielding displacement $\Delta_{y}$ of specimens.

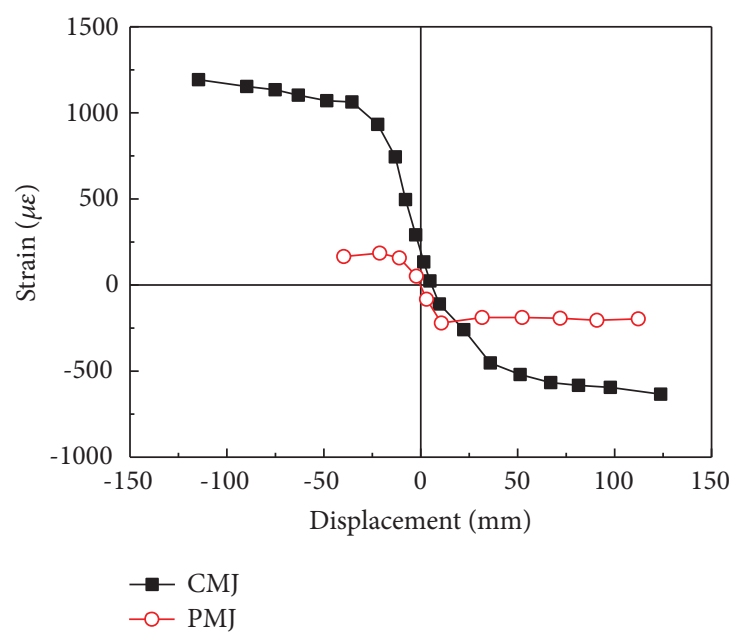

FIGURE 7: Relationship curves between steel strain and deformation of loading end.

the shear deformation resulted in pinching of hysteresis loop and reducing energy consumption, as pointed by previous studies [36]. On the basis of tested results, it can be seen that failure was characterized by failing in crushing and spalling of the concrete in the core region, while few bending cracks were observed in the column and beam elements. That is to say, the performance of the specimen was controlled by the shear behavior in the core region instead of the bending behavior of beams or columns. Therefore, the steel strains and shear deformation of the core region were measured.

4.1. Strain of Reinforcement Steel. In order to study the difference of shear behavior in the core region of precast beam-slab-column joint and cast-in-place joint, steel strain gauges were mounted in the transverse reinforcement within the core region to monitor strain responses at various locations, as presented in Figure 4. One can see from Figure 9 that transverse reinforcement was at the tension state, which illustrated that the compressive stress in the core region was borne by the concrete. There was a noticeable difference in the strain change trend between the two specimens. As observed in specimen CMJ, the strain changed compatibly with the deformation of beam-end, but the unobvious change trend was observed in the precast specimen. The position of maximum strain was also different because of the presence of beam corbel. The concrete slab can confine the joint core region to improve the shear strength. For precast specimens, this restraint effect was also from the contribution of beam corbels except for concrete slabs, which lead 


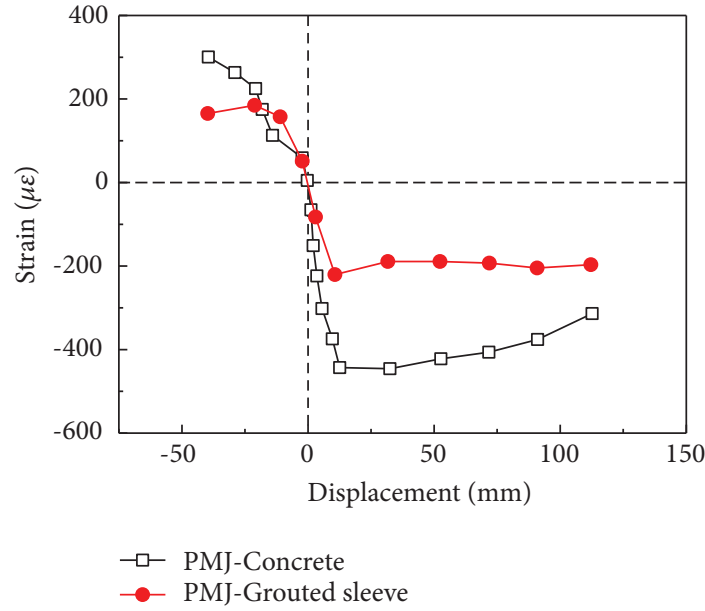

(a)

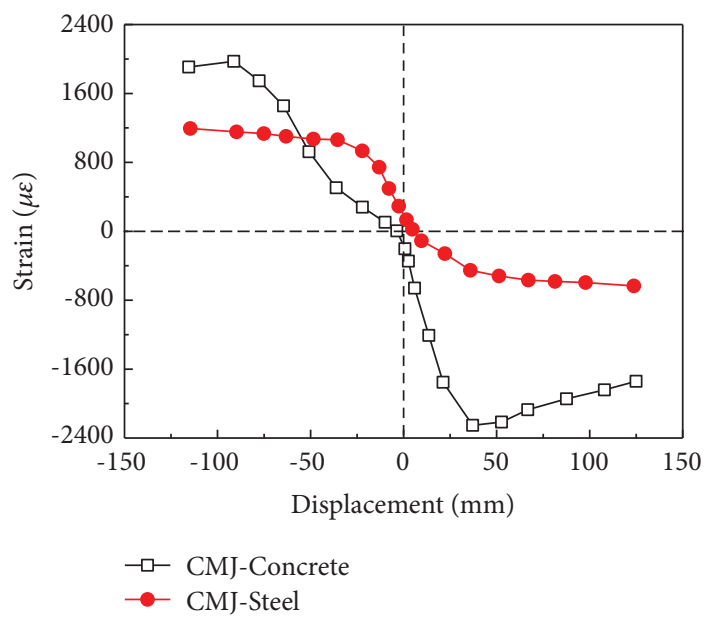

(b)

FIGURE 8: Representative comparisons of strain between concrete and steel: (a) specimen PMJ and (b) specimen CMJ.

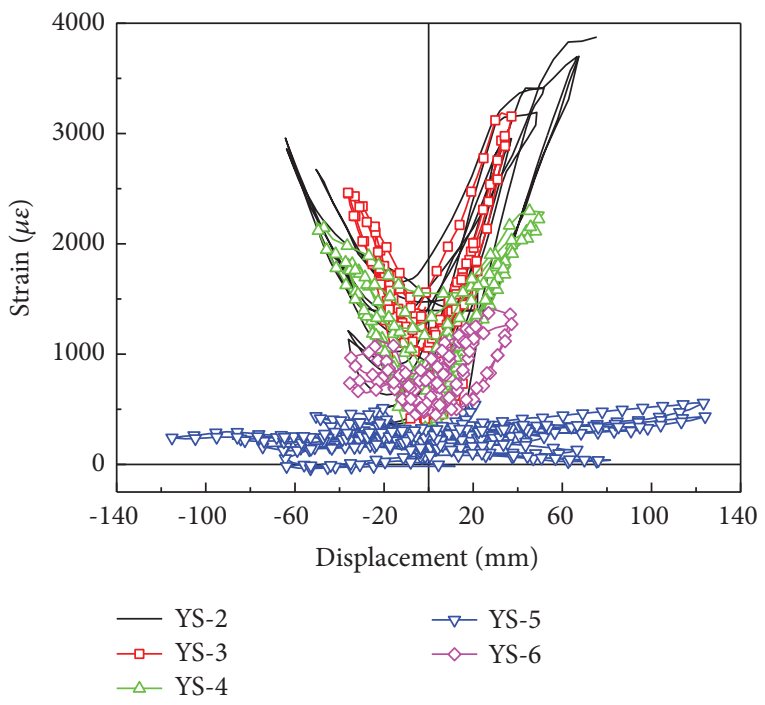

(a)

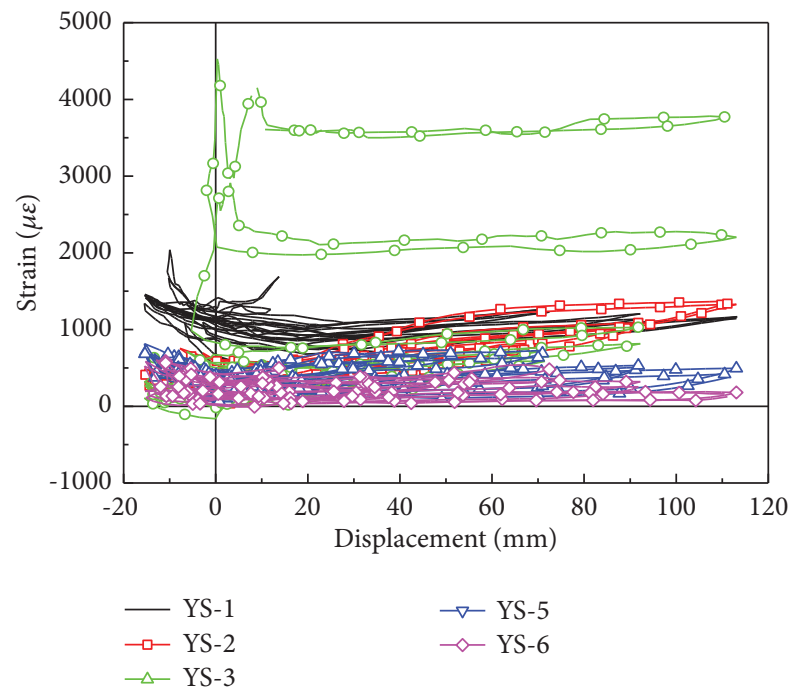

(b)

FIGURE 9: Joint stirrup strain versus deformation relationships of specimens: (a) specimen CMJ and (b) specimen PMJ.

to the remarkable increase of the stirrup strain at the lower edge of precast beam corbels. The main reason for the above observations was as follows: (1) beam corbels increased the shear area of the core region, which changed the forcing proportion of truss mechanism and compression strut mechanism in the core region of joint and (2) the interface between the precast beam and postpouring core region weakened the deformation of the core region, which resulted in insignificant changes in the stirrups in the core region.

$$
\gamma=\frac{\sqrt{h_{2}+b_{2}}}{h b} \frac{\left|\Delta_{1}+\Delta_{2}\right|+\left|\Delta_{1}^{\prime}+\Delta_{2}^{\prime}\right|}{2} .
$$

Apart from the stirrup strain of transverse reinforcement, the shear deformation, $\gamma$, of the core region was measured by two dial indicators $X_{1}$ and $X_{2}$ and calculated by the following formulation, as shown in equation (4) [21].
$\Delta_{1}, \Delta_{1}^{\prime}, \Delta_{2}, \Delta_{2}^{\prime}$ were the diagonal deformation of the core region according to dial indicators $X_{1}$ and $X_{2}$, respectively; $h$ and $b$ were the section height and width of the core region, respectively. The shear deformation lead to forming inclined shear cracks, and the core region had a deformation trend similar to "rhombus." The shear angle of PMJ was generally lower than that of specimen CMJ, and the maximum shear angle was only $80 \%$ of that of conventional cast-in-cast specimens. Furthermore, the relation of shear angle and displacement of specimen PMJ was close to linear.

In light of the above-mentioned stirrup strain and shear angle, the shear mode in the core region was different obviously. Based on the previous knowledge that the beam element of specimen PMJ exhibited a significant stiffness caused by corbels, the shear deformation of the core region could be improved. However, it was obviously different from 
the experimental results, and the reason was probably that the influence of corbels on the shear strength of the core region was neglected. The shear strength of the core region was improved by an increase in the shear area. Therefore, there was no doubt that corbels provided important insights into the influence on the shear behavior of the core region, which will be discussed and analyzed in the next section.

4.2. Shear Strength Analysis of the Core Region. Based on the aforementioned test results, it indicated that the shear strength of the core region has remarkable effects on the failure mode and loading capacity of beam-slab-column joints. Therefore, the relationship of shear stress and strain in the core region should be researched, which also lays a foundation for further investigations of numerical models, such as the Pinching4 material model of OpenSees, which is an object-oriented open source FE software program, as shown in Figure 10. The mechanical performance of the joint core region that was constrained by the surrounding elements (column, beam, and slab) was complicated. Therefore, take the precast experimental specimen as an example; the longitudinal and transverse reinforcement ratios were 1.7\% and $1.6 \%$, respectively. Meanwhile, the ratio of reinforcement of the core region was consistent with that of original specimens when the researched area was changed. The influence of different axial pressure stress and thickness on the shear behavior of the core region was studied.

4.2.1. Axial Compression Ratio. The size (i.e., area or volume) and compression stress of the core region adopted in the beam-slab-plate joint were of crucial importance for the performance in terms of shear strength, stiffness, and shear deformation. Moreover, there was a noticeable difference in the compression stress between the column section and the core region section. In order to be consistent with the study parameters in the test, the standard of the axial compression ratio of column end was adopted. The relationship of shear stress and strain in the joint core region was studied by the modified compression field theory (MCFT).

It can be found from Figure 11 that the shear strength in the core region improved with respect to the pressure stress. On the contrary, the shear strain corresponding to the maximum shear stress had a trend of decreasing as the pressure stress. Meanwhile, there was a platform process of stress-strain curves at each state of the loading history, but it decreased monotonously with increasing of the vertical compression stress, as shown in Figure 11. The shear behavior of the joint was identical to the respective mechanical performance observed in the precast column subjected to different compression ratios. In light of the above-mentioned results, the shear behavior of the core region was strongly affected by the surrounding stress, which was transferred by the columns and beams. With respect to experimental specimens, the unbalanced shear stress on both sides of the core region was caused by the different positive and negative bending moments of members, which illustrated that the shear behavior exhibited a dynamic process caused by the different pressure stress at each forcing

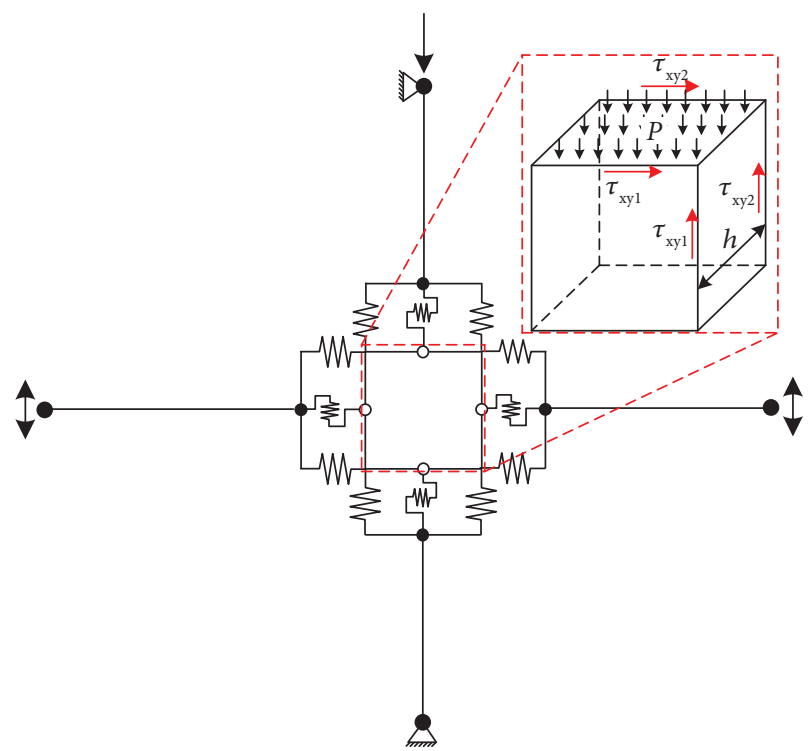

FIgURE 10: A two-dimensional calculated model of beam-columnjoint.

state. Therefore, a uniaxial material model of shear stressstrain adopted in the Pinching4 in the OpenSees was difficult to be reached.

4.2.2. The Influence Analysis of Corbel on Shear Strength. Exactly for vertical pressure stress, the size of the core region proved to play a crucial role in the shear behavior. Compared to the cast-in-place specimen, the beam corbel increased the shear area of the core region. The shear behavior of reinforced concrete slabs was modeled with the MCFT, which was derived from assumptions that the stress and strain distribution in the thickness direction was consistent. Therefore, the thickness of the core region needed to be equivalently simplified, as shown in Figure 12. The partial area of corbel, $S_{1}$, was arranged to the lower part of the core region, $S_{2}$. Furthermore, the area of $S_{1}$ was equal to that of $S_{2}$, and the thickness was constant through the height.

It was noteworthy that the cracking distribution was affected by this simplified treatment method, which was beyond the scope of this paper. Exactly for this, the pressure stress transferred to the section of the core region increased monotonously with decreasing of the core region area under the same constant column axial compressive load acted on column end. In addition, the name of the specimen was dented as $0.85-\times \times$. Namely, 0.85 represented the axial compression ratio of column-end, and the $x \times$ was the thickness of the joint core region.

As a result, the maximum shear stress in the core region degraded with the increase in the thickness of the core region, and the main reason for the above observations was that the pressure stress was improved by the decrease of forcing area in the core region. On the basis of the abovementioned results, the pressure stress increased the shear stress of the core region. Shear capacity was defined as the product of shear stress and volume of the core region. Although the shear stress decreased with the increment of the 


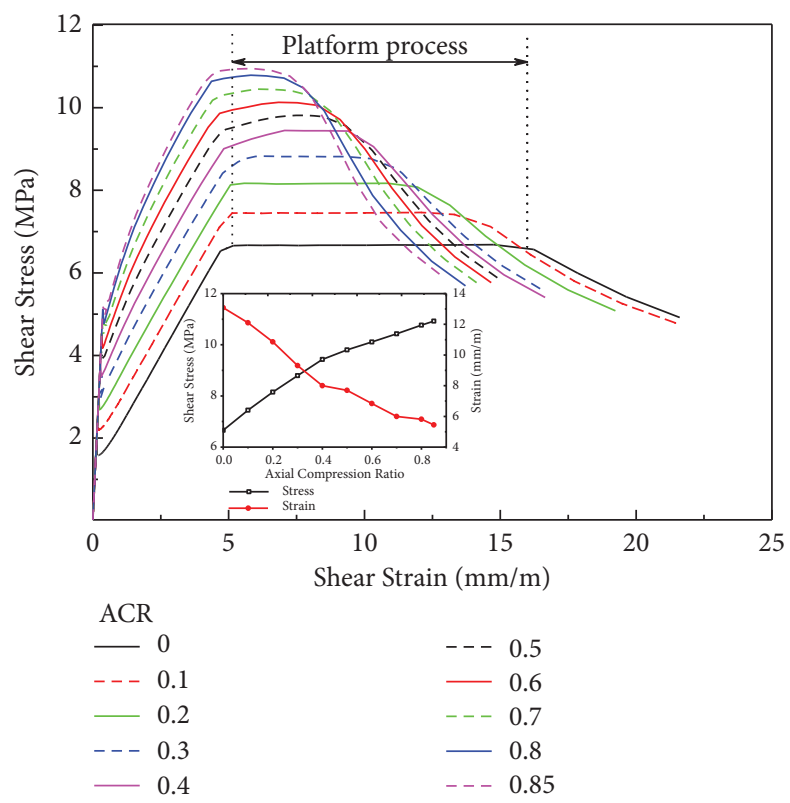

Figure 11: Relationship curve of shear strain and stress of core region subjected to different vertical stress.

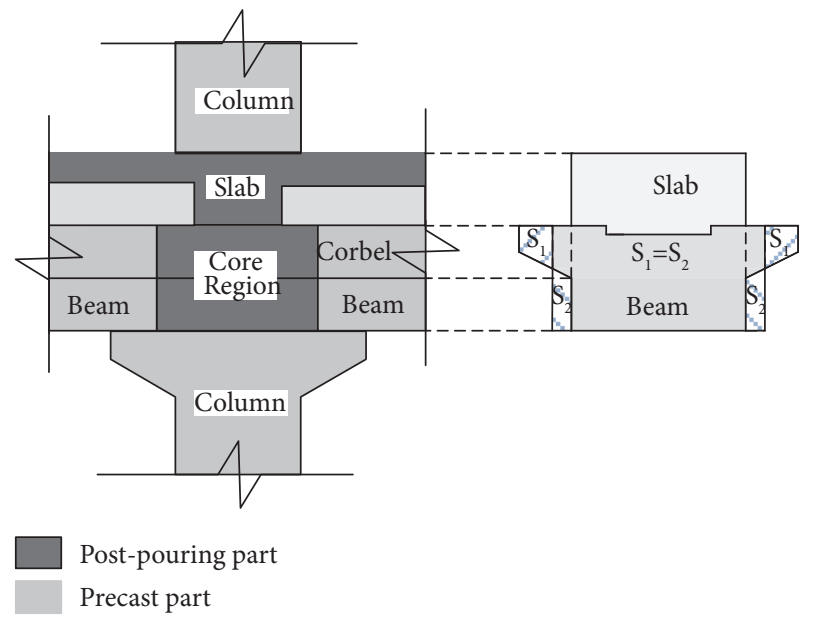

FIgURE 12: Simplified model of core region of assembled joint.

area of the core region, the shear capacity was gradually increasing, as shown in Figure 13. The corbel increased the shear area of the joint, which was beneficial to realize the design ideas of strong-joint-weak-member.

\section{Designed Analysis of Corbel}

In light of the above-mentioned experimental results, corbels had remarkable effects on the failure mode. In particular, the beam corbel can increase the shear strength of the core region, and the influence of the beam corbels on the slab can be detailed in a standalone paper [45]. Based on the aforementioned designed works, the reinforcement was able to meet the cracking requirement. However, one inclined crack was observed in the precast column corbel. Therefore, the designed work about reinforcement concrete corbels should be taken into account. Especially, when it was uncertain how much load could be subjected to corbel, which depended on a lot of factors including the boundary conditions (beam and core region), contact method and element type, and so on. For the sake of simplicity, it was classified into three calculated conditions, as shown in Figure 13. Condition A was fixed connection between beam and core region of specimen, which was in line with the real state of joint in this experiment and classified as rigid or wet connections, as shown Figure 14(a); Condition B was the hinged connection, which was generally used in steel structures, as shown Figure 14(b); and Condition C stands for no connection, which was grouped into dry connection and expressed by the specification [37], as illustrated in Figure 14(c).

$$
\begin{aligned}
& F_{v 1}=F_{e x}+F_{e x} \frac{b_{1}}{b_{0}}-\frac{M_{c}}{b_{0}} . \\
& F_{v 2}=F_{e x}+F_{e x} \frac{b_{1}}{b_{0}} . \\
& F_{v 3}=F_{e x} .
\end{aligned}
$$

The force subjected to the corbel of columns for the different conditions was reached by the force equilibrium method, as shown in equations (5)-(7). One can see that there was a noticeable difference in load, $F_{v}\left(F_{v 1}, F_{v 2}\right.$, and $\left.F_{v 3}\right)$, using different anchorage arrangements in precast concrete structures. The hinged connection was largest; the fixed connection was the second larger; and the free connection was the weakest. Although the slight discrepancies in the real state and experimental condition, some designed suggestions can be obtained. Precast column corbels can avoid installing vertical supports and improve the convenience of the installation of precast elements. Moreover, this was attributed to 


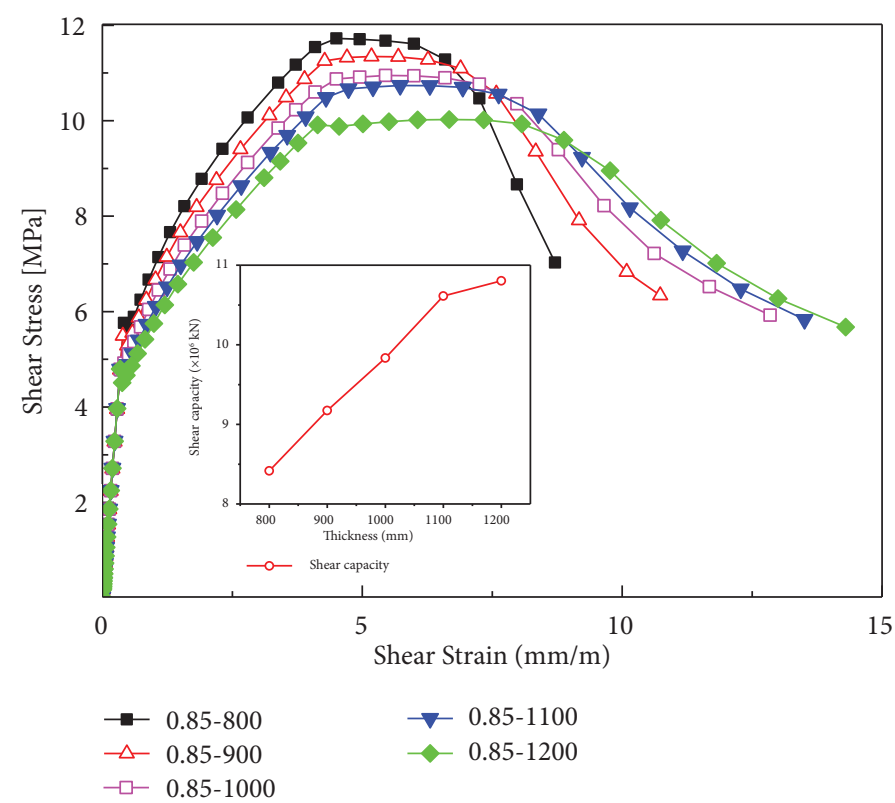

FIGURE 13: The influence of the thickness of the core region on the shear performance.

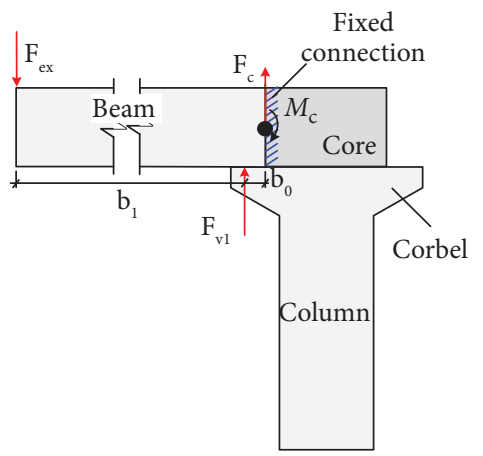

(a)

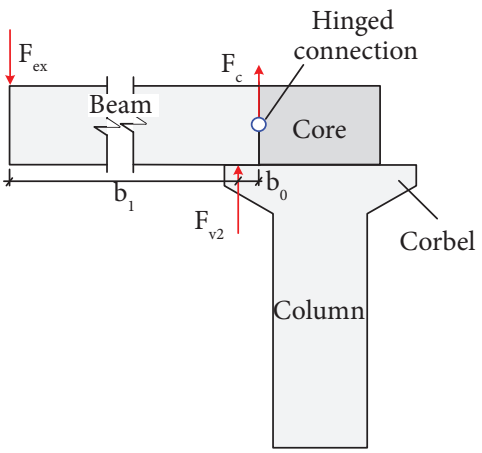

(b)

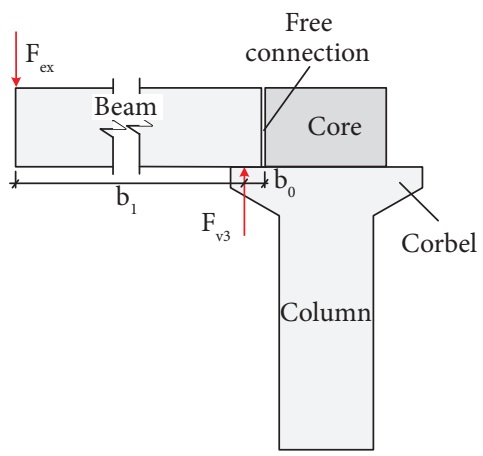

(c)

FIGURE 14: Simplified calculation model: (a) fixed connection, (b) hinged connection, and (c) free connection.

the presence of corbels in the column, in which the partial vertical load was shifted from beam ends, which made it easier to meet the shear strength adjacent to the joint core region. However, from the perspective of test results, corbels may be damaged due to insufficient strength. Just like the center column of the underground structure that was considered to be components with high load-bearing capacity and stiffness to provide vertical load rather than the horizontal load. In other words, the underground structure could be much safer due to the center column has been born partial load. However, the vertical bearing capacity of the column was affected by the horizontal deformation [5].

\section{Conclusion}

The quasi-static experiments were conducted with the primary objective of the seismic performance of full-scale beam-slab-column interior joint with corbels and cast-inplace specimen without corbels taken out from the underground subway station. Based on the experimental results, the shear behavior of the core region was studied with respect to different parameters. Meanwhile, the designed load of column corbels was discussed. The following conclusions can be drawn:

(1) The noticeable differences between the precast and cast-in-place beam-slab-column interior joints were the amount of cracking and damage. For the cast-inplace specimen, well-distributed inclined shear cracks formed; concrete cover spalled completely in the core region of joints; and flexural cracks were concentrated in the plastic hinge zone of the beams. However, more local damage was observed for the precast concrete specimen with the gap between precast elements, especially the splitting cracks developed at the laminated slab.

(2) In terms of the failure mode of the core region, the knowledge about the forcing mechanism of the core region of two reference joints was in different ways. The corbel beam increased the shear area and the opening gap (assembled seams) contributed to the global deformation, which was in line with the 
strong-joint-weak-member concept in the seismicresistant design.

(3) A simplified approach to deal with corbels in the core region that facilitates the use of modified compression field theory was proposed, which provided qualitative measures to evaluate the influence of corbels on the shear behavior of the core region under quasi-static lateral cyclic loading.

(4) The pressure stress and thickness of the core joint had remarkable effects on increasing the shear stress and strain. The shear stress increased with respect to the pressure stress, but the shear strain had a trend of decreasing. While shear stress decreased with increment of the area of the core region subjected to constant pressure stress, and the shear capacity was gradually increasing.

(5) The effect of the designed load of column corbels was scenario-dependent and associated with connection methods between the laminated beam and core region.

Overall, the precast concrete beam-slab-column joints were capable of matching the overall performance of the monolithic connections according to test results. However, making more accurate recommendations and considerations about connection technology between precast concrete parts needed deeper numerical or experimental investigations by examining more precast reinforcement concrete specimens.

\section{Data Availability}

All data, models, and code generated or used during the study appear in the submitted article.

\section{Conflicts of Interest}

The authors declare that they have no conflicts of interest or personal relationships that could have appeared to influence the work reported in this paper.

\section{Acknowledgments}

This work was supported by the Beijing Natural Science Foundation (8204054), the National Natural Science Foundation of China (51908013), and the Basic Scientific Research Foundation for Municipal University (X21076). Their supports are gratefully acknowledged.

\section{References}

[1] J. D. Nzabonimpa and W.-K. Hong, "Experimental and nonlinear numerical analysis of precast concrete column splices with high-yield metal plates," Journal of Structural Engineering, vol. 145, no. 2, Article ID 04018254, 2019.

[2] H. Liu, C. Xu, and X. Du, "Seismic response analysis of assembled monolithic subway station in the transverse direction," Engineering Structures, vol. 219, Article ID 110970, 2020.
[3] T. Chen, F. Luo, X. Du, S. Li, and Z. Wang, Study on Seismic Properties of Assembled Monolithic Metro Station Based on Response Deformation Method, Atlantis Press, Amsterdam, Netherlands, 2016.

[4] R. Dong, L. Jing, Y. Li, Z. Yin, G. Wang, and K. Xu, "Seismic deformation mode transformation of rectangular underground structure caused by component failure," Tunnelling and Underground Space Technology, vol. 98, Article ID 103298, 2020.

[5] V.-Q. Nguyen, Z. A. Nizamani, D. Park, and O.-S. Kwon, "Numerical simulation of damage evolution of Daikai station during the 1995 Kobe earthquake," Engineering Structures, vol. 206, Article ID 110180, 2020.

[6] D.-C. Feng, G. Wu, and Y. Lu, "Finite element modelling approach for precast reinforced concrete beam-to-column connections under cyclic loading," Engineering Structures, vol. 174, pp. 49-66, 2018.

[7] A. Baghdadi, M. Heristchian, L. Ledderose, and H. Kloft, "Experimental and numerical assessment of new precast concrete connections under bending loads," Engineering Structures, vol. 212, Article ID 110456, 2020.

[8] M. N. Kataoka, M. A. Ferreira, and A. L. H. de Cresce El Debs, "Nonlinear FE analysis of slab-beam-column connection in precast concrete structures," Engineering Structures, vol. 143, pp. 306-315, 2017.

[9] S. Megally, F. Frieder Seible, and R. K. Dowell, "Seismic performance of precast segmental bridges: segment-to-segment joints subjected to high flexural moments and low shears," PCI Journal, vol. 48, no. 2, pp. 80-96, 2003.

[10] F. Seible and C. T. Latham, "Horizontal load transfer in structural concrete bridge deck overlays," Journal of Structural Engineering, vol. 116, no. 10, pp. 2691-2710, 1990.

[11] N. J. Brooke, L. M. Megget, and J. M. Ingham, "Bond performance of interior beam-column joints with high-strength reinforcement," ACI Materials Journal, vol. 103, no. 4, pp. 596-603, 2006.

[12] J. Kashyap, C. R. Willis, M. C. Griffith, J. M. Ingham, and M. J. Masia, "Debonding resistance of FRP-to-clay brick masonry joints," Engineering Structures, vol. 41, pp. 186-198, 2012.

[13] M. J. N. Priestley, S. Sritharan, J. R. Conley, and S. Stefano Pampanin, "Preliminary results and conclusions from the PRESSS five-story precast concrete test building," PCI Journal, vol. 44, no. 6, pp. 42-67, 1999.

[14] M. J. N. Priestley and G. A. MacRae, "Seismic tests of precast beam-to-column joint subassemblages with unbonded tendons,” PCI Journal, vol. 41, no. 1, pp. 64-81, 1996.

[15] M. J. N. Priestley, "Overview of PRESSS research program," PCI Journal, vol. 36, no. 4, pp. 50-57, 1991.

[16] J. Shafaei, A. Hosseini, M. S. Marefat, and J. M. Ingham, "Rehabilitation of earthquake damaged external RC beamcolumn joints by joint enlargement using prestressed steel angles," Earthquake Engineering \& Structural Dynamics, vol. 46, no. 2, pp. 291-316, 2017.

[17] J. Shafaei, A. Hosseini, M. S. Marefat, J. M. Ingham, and H. Zare, "Experimental evaluation of seismically and nonseismically detailed external RC beam-column joints," Journal of Earthquake Engineering, vol. 21, no. 5, pp. 776-807, 2017.

[18] H. M. Elsanadedy, "New moment-resisting beam-column joints to increase progressive collapse resistance of precast concrete buildings," Journal of Building Engineering, vol. 44, Article ID 102884, 2021.

[19] W. Huang, G. Hu, X. Miao, and Z. Fan, "Seismic performance analysis of a novel demountable precast concrete beam- 
column connection with multi-slit devices," Journal of Building Engineering, vol. 44, Article ID 102663, 2021.

[20] B. Li, E. S.-s. Lam, B. Wu, and Y.-y. Wang, "Experimental investigation on reinforced concrete interior beam-column joints rehabilitated by ferrocement jackets," Engineering Structures, vol. 56, pp. 897-909, 2013.

[21] H. Liu, J. Chen, C. Xu, and X. Du, "Seismic performance of precast column connected with grouted sleeve connectors," Journal of Building Engineering, vol. 31, Article ID 101410, 2020.

[22] H. Liu and X. Du, "Seismic performance of precast joint in assembled monolithic station: effect of assembled seam shape and position," Earthquakes and Structures, vol. 17, no. 6, pp. 611-621, 2019.

[23] H. Liu, Z. Wang, X. Du, and G. Q. P. Shen, "The seismic behaviour of precast concrete interior joints with different connection methods in assembled monolithic subway station," Engineering Structures, vol. 232, Article ID 111799, 2021.

[24] M. E. Gulsan and M. A. Shaikhan, "A new method for repair of fiber reinforced concrete corbels using steel threaded rods," Earthquakes and Structures, vol. 15, no. 2, pp. 165-178, 2018.

[25] R. Ad Souza, L. M. Trautwein, and MdP. Ferreira, "Reinforced concrete corbel strengthened using carbon fiber reinforced polymer (CFRP) sheets," Journal of Composites Science, vol. 3, no. 1, pp. 1-13, 2019.

[26] H.-H. Tsang, "Innovative upscaling of architectural elements for strengthening building structures," Sustainability, vol. 11, no. 9, p. 2636, 2019.

[27] S. Ahmad, A. Shah, A. Nawaz, and K. Salimullah, "Refuerzo a cortante de ménsulas con polímeros reforzados con fibra de carbono (CFRP)," Materiales de Construcción, vol. 60, no. 299, pp. 79-97, 2010.

[28] I. Ivanova and J. Assih, "Experimental study of local behavior of strengthened reinforced concrete short corbel by bonding carbon fiber fabrics," International Journal of Structural and Civil Engineering Research, vol. 4, no. 1, pp. 148-158, 2015.

[29] I. Ivanova, J. Assih, A. Li, D. Dontchev, and Y. Delmas, "Experimental investigation into strengthened short reinforced concrete corbels by bonding carbon fiber fabrics," Journal of Adhesion Science and Technology, vol. 29, no. 20, pp. 2176-2189, 2015.

[30] T. A. El-Maaddawy and E.-S. I. Sherif, "Response of concrete corbels reinforced with internal steel rebars and external composite sheets: experimental testing and finite element modeling," Journal of Composites for Construction, vol. 18, no. 1, Article ID 04013020, 2014.

[31] R. C. Neupane, L. Eddy, and K. Nagai, "Investigation on strengthening approaches adopted for poorly detailed RC corbels," Fibers, vol. 5, no. 2, pp. 1-15, 2017.

[32] E. C. Bentz, F. J. Vecchio, and M. P. Collins, "Simplified modified compression field theory for calculating shear strength of reinforced concrete elements," ACI Structural Journal, vol. 103, no. 4, pp. 614-624, 2006.

[33] F. J. Vecchio and M. P. Collins, "The modified compressionfield theory for reinforced concrete elements subjected to shear," ACI Journal, vol. 83, no. 2, pp. 219-231, 1986.

[34] X. Du, H. Liu, C. Xu, L. Jin, F. Luo, and L. Songmei, "Study on seismic performance of beam-column-slab interior joints in longitudinal section of assembled monolithic subway station," Journal of Building Structures, vol. 40, no. 9, pp. 95-103, 2019.

[35] H. Wang, F. Barbagallo, and P. Pan, "Test of precast prestressed beam-to-column joint with damage-free reinforced concrete slab," Engineering Structures, vol. 210, Article ID 110368, 2020.

[36] H. Liu, Z. Wang, and X. Du, "Influence of axial compression ratio on the seismic performance of precast columns with grouted sleeve connections," Journal of Structural Engineering, vol. 147, no. 12, pp. 1-14, 2021.

[37] Cmc, GB50010-2010 Code for Design of concrete Structures, 2010.

[38] Aci, Building Code Requirements for Structural concrete (ACI 318-02) and Commentary (ACI 318R-02)American Concrete Institute, Michigan, USA, 2002.

[39] G. Campione and F. Cannella, "Analytical model for flexural response of reinforced concrete corbels externally strengthened with fiber-reinforced polymer," ACI Structural Journal, vol. 117, no. 4, pp. 91-102, 2020.

[40] X. Du, H. Liu, C. Xu, L. Jin, F. Luo, and L. Songmei, "Study on seismic performance of sidewall joints in assembled monolithic subway station," China Civil Engineering Journal, vol. 50, no. 4, pp. 38-47, 2017.

[41] Cmc Jgj/T 101-2015, Specification of Seismic Test of Building, China Architecture and Building Press, Beijing, China, 2015.

[42] Z. B. Haber, M. S. Saiidi, and D. H. Sanders, "Behavior and simplified modeling of mechanical reinforcing bar splices," ACI Structural Journal, vol. 112, no. 2, pp. 179-188, 2015.

[43] X. M. Zhai, C. X. Xiong, and Y. L. Gan, "Experimental study and numerical simulation on assembled frame with doublebeam multi-column joints," Journal of Harbin Institute of Technology, vol. 52, no. 8, pp. 81-87, 2020.

[44] X. Xu, R. Cheng, P. Yang, and R. Liu, "Cyclic loading test for concrete-filled U-shaped steel beam to concrete-filled steel tube column connections," International Journal of Steel Structures, vol. 20, no. 6, pp. 1859-1870, 2020.

[45] J. F. Rave-Arango, C. A. Blandón, J. I. Restrepo, and F. Carmona, "Seismic performance of precast concrete column-to-column lap-splice connections," Engineering Structures, vol. 172, pp. 687-699, 2018. 